\title{
IMPLEMENTASI METODE MIND MAPPING UNTUK MENINGKATKAN MINAT DAN KOMPETENSI WRITING SISWA KELAS VII D SMPN 5 KOPANG
}

\author{
H. Ruslan Abdul Gani \\ Guru SMP Negeri 5 Kopang, ruslanabdgani@gmail.com
}

\begin{tabular}{|c|c|}
\hline INFO ARTIKEL & $\begin{array}{r}\text { ABSTRAK } \\
\end{array}$ \\
\hline Riwayat Artikel: & $\begin{array}{l}\text { Abstrak: Penelitian Tindakan Kelas dilakukan } 2 \text { siklus terhadap kelas VII D SMPN } 5 \\
\text { Kopang tahun 2014/2015, menggunakan metode pengumpulan data Observasi, }\end{array}$ \\
\hline $\begin{array}{l}\text { Diterima: } 17-02-2018 \\
\text { Disetujui: 18-03-2018 }\end{array}$ & $\begin{array}{l}\text { Interview, dan dokumentasi, serta tes tentang peningkatan kompetensi dan prestasi } \\
\text { writing siswa.. diperoleh nilai rata-rata prestasi dan kompetensi writing bahwa } \\
\text { ketuntasan klasikal pada siklus I } 89 \% \text {. Sedangkan pada siklus II terjadi peningkatan }\end{array}$ \\
\hline Kata Kunci: & $\begin{array}{l}\text { mind mapping dapat meningkatkan minat dan kompetensi writing siswa pada } \\
\text { pembelajaran procedure text kelas VII-D SMP Negeri } 5 \text { Kopang tahun pelajaran } \\
2014 / 2015 \text {. }\end{array}$ \\
\hline
\end{tabular}

Mind Mapping,

Writing

\begin{abstract}
Classroom Action Research conducted 2 cycles to class VII D SMPN 5 Kopang year 2014/2015, using Observation data collection method, Interview, and documentation, and test about improving competence and writing achievement of student .. obtained by average value of achievement and competence writing that classical completeness in cycle I 89\%. While in cycle II there is increase of classical mastery by $6 \%$ to $95 \%$. It was concluded that the application of mind mapping method can increase interest and writing competence of students on learning text procedure of class VII-D of SMP Negeri 5 Kopang for academic year 2014/2015.
\end{abstract}

\section{A. LATAR BELAKANG}

Mata pelajaran Bahasa Inggris mempunyai karakteristik yang berbeda dengan mata pelajaran lain. Perbedaan ini terletak pada fungsi bahasa sebagai alat komunikasi. Selain diperlukan penguasaan kosa kata dan tata bahasa, juga diperlukan keterampilan dalam mengaplikasikannya dalam kegiatan komunikasi, baik lesan maupun tulis (Depdiknas, 2006:2). Pada pembelajaran kompetensi atau aspek writing, yang tujuan akhirnya adalah memproduk atau menghasilkan tulisan atau teks baik fungsional maupun monolog berdasarkan genre atau jenis teks, diharapkan siswa dapat memahami ciri-ciri dari suatu teks, dan dapat mengekspresikannya dengan kosa kata dan tata bahasa yang benar.

Di SMP Negeri 5 Kopang, banyak siswa khususnya kelas VII yang merasa kesulitan dalam mengikuti pelajaran Bahasa Inggris khususnya pada aspek writing. Sebagai contoh, pada waktu diberi tugas menulis teks monolog berbentuk descriptive yang sudah ditentukan tema atau judulnya, kebanyakan siswa tidak segera melaksanakan, bahkan malah ditinggal ngobrol dengan teman di dekatnya. Nampak tidak serius dan malas mengerjakannya. Waktu diperingatkan dan ditanya kenapa tidak segera dikerjakan, jawaban mereka : "Sebentar ...", "Nanti dulu, bu,", "Sulit, bu,", "Buat PR aja, bu" ...dan seterusnya yang intinya ingin menghindari tugas itu. Padahal langkah-langkah menulis descriptive sudah peneliti berikan, seperti pola kalimat simple present tense, contoh-contoh cara membuat kalimatnya, menentukan kosa kata yang akan digunakan, yang berkaitan dengan tema yang sedang dipelajari serta generic structurenya juga sudah diberikan. Contoh descriptive text pun sudah diberikan dalam pembelajaran aspek reading.

Masalah yang dihadapi kebanyakan siswa kelas VII SMP Negeri 5 Kopang pada pembelajaran aspek writing ini cukup kompleks. Mulai dari kurangnya minat, kurangnya sarana, kurangnya motivasi sehingga kurang serius dalam mengikuti mata pelajaran Bahasa Inggris sehingga berdampak pada lemahnya penguasaan kosa kata dan tata bahasa yang sangat diperlukan dalam pembelajaran aspek writing ini. Kalau melihat macetnya penulisan, itu berarti karena kurangnya pengorganisasian pokok pikiran.

Berdasarkan permasalahan-permasalahan tersebut di atas, peneliti mencoba menggunakan metode mind mapping untuk mengatasi sebagian dari permasalahanpermasalahan itu. Metode mind mapping adalah metode meringkas yang menggunakan segala macam metode untuk memudahkan mengingat, tapi hanya passwordpassword saja yang diletakkan pada mind mapping. (Diklat 
Peningkatan Mutu dan Profesionalisme Guru, 2006, Neuroscience Super Teaching: 55). Mind mapping dapat memunculkan ide, dapat mengembangkan ide dan menarik, karena dapat diberi gambar-gambar yang menarik sesuai dengan ide yang muncul serta dapat diberi warna yang menarik pula.

Menurut Anton, Mind Mapping atau Peta Pikiran adalah metode mempelajari konsep yang ditemukan oleh Tony Buzan. Konsep ini didasarkan pada cara kerja otak kita menyimpan informasi. Hasil penelitian menunjukkan bahwa otak kita tidak menyimpan informasi dalam kotakkotak sel saraf yang terjejer rapi melainkan dikumpulkan pada sel-sel saraf yang berbercabang-cabang yang apabila dilihat sekilas akan tampak seperti cabang-cabang pohon. Temuan Buzan ini didasarkan pada hasil riset Roger Sperry-ahli Biologi peraih hadiah nobel dalam bidang fisiologi dan kedokteran yang menunjukkan bahwa otak memiliki 2 belahan yang masing-masing belahan bekerja secara sangat berbeda. Secara ringkas, otak kiri bersifat rasional dan otak kanan lebih emosional. Menurut Buzan, dengan memanfaatkan gambar dan teks ketika kita mencatat atau mengeluarkan sesuatu yang ada di dalam diri, maka kita telah menggunakan dua belahan otak secara sinergis. Apalagi jika dalam peta pikiran itu, kemudian ditambahkan warna dan hal-hal yang memperkuat emosi.

Metode ini dapat menjawab permasalahan siswa di atas sehingga siswa menjadi lebih tertarik untuk mengikuti mata pelajaran Bahasa Inggris. Bagi siswa yang suka menggambar, dapat mengekspresikan gagasannya melalui gambar yang beraneka ragam dan warna dalam mind mappingnya. Ketika siswa sudah merasa tertarik, guru akan lebih mudah dalam menyampaikan materi kepada siswa. Selain itu pula siswa tidak lagi merasa kesulitan dalam mengikuti pelajaran Bahasa Inggris khususnya pada kompetensi atau aspek writing.

Tujuan dari penelitian ini adalah untuk meningkatkan minat dan kompetensi writing siswa kelas VII-D SMP Negeri 5 Kopang Tahun Pelajaran 2014/2015 pada Materi procedure text dengan menerapkan metode pembelajaran mind mapping.

\section{B. METODE PENELITIAN}

Penelitian ini dilakukan dengan metode penelitian tindakan kelas (PTK). Menurut Kasbolah (1999:15), penelitian tindakan kelas merupakan penelitian dibidang pendidikan yang dilaksanakan di dalam kelas dengan tujuan untuk memperbaiki atau meningkatkan kualitas pembelajaran. Adapun subyek penelitiannya adalah siswa kelas VII-D SMP Negeri 5 Kopang tahun ajaran 2014/2015 yang terdiri dari 37 orang.

Ada beberapa faktor yang akan diteliti yaitu faktor siswa dan guru. Faktor siswa yang dimaksud adalah minat dan kompetensi writing siswa pada pembelajaran procedure text dengan metode mind mapping. Sedangkan faktor guru yang dimaksud adalah kesesuaian aktivitas guru dengan langkah-langkah metode mind mapping selama proses pembelajaran di kelas pada materi procedure text.

Penelitian tindakan kelas ini dilaksanakan dalam dua siklus. Pada siklus pertama dan kedua terdiri dari tiga kali pertemuan dengan rincian dua kali pertemuan untuk kegiatan pembelajaran dan satu pertemuan untuk kegiatan evaluasi. Adapun tahapan dalam tiap siklusnya adalah tahap perencanaan, pelaksanaan tindakan, observasi, evaluasi, dan refleksi diakhir tindakan.

Siklus pertama dilaksanakan pembelajaran writing dengan materi descriptive text yang dilksanakan dalam 8 kali pertemuan. Setiap minggunya kelas VII D bertatapmuka sebanyak 2 kali, yaitu setiap hari Rabu dan Sabtu. Setiap pertemuan 2 jam a 40 menit. Sebelum penelitian dimulai terlebih dahulu diberitahukan bahwa di kelas ini akan diadakan penelitian tindakan kelas oleh peneliti, yang melibatkan seluruh siswa kelas VII D dan seorang pengamat, yaitu guru Bahasa Inggris lain. Tindakan yang akan dilakukan meliputi pengisian angket, pretes, postes, tugas kelompok, tugas individu dan refleksi dengan siswa maupun dengan pengamat atau kolaborator.

Sedangkan siklus kedua dilaksanakan pembeljaran writing dengan materi procedure text. Pembelajaran ini dilksanakan dalam 7 kali pertemuan. Langkah-langkah pembelajarannya seperti langkah-langkah pada siklus pertama dengan perubahan yang sifatnya menyempurnakan siklus pertama, berdasarkan hasil refleksi dengan siswa dan kolaborator pada siklus pertama. Di akhir penelitian, setelah ulangan harian yang berfungsi sebagai postes siklus kedua, kemudian refleksi, lalu mengisi angket lagi seperti pada permulaan penelitian. Tujuannya untuk mengetahui apakah ada perubahan atau tidak setelah diadakannya tindakan. Kalau ada, perubahannya kearah mana.

Observasi atau pengamatan penelitian, dilakukan oleh kolaborator, testee, yaitu siswa yang diteliti dan peneliti sendiri. Kolaborator mengamati setiap pertemuan dan mencatat atau mengisi lembar pengamatan yang disediakan peneliti. Siswa bersama guru (peneliti) melaksanakan pembelajaran dengan langkah-langkah sesuai RPP yang dibuat dengan mengacu pada implementasi metode mind mapping. Hasil pengamatan siswa dicatat oleh peneliti pada waktu refleksi dengan cara tanya jawab secara lisan. Alat observasi berupa lembar pengamatan yang diberikan kepada kolaborator untuk diisi pada waktu mengamati jalannya pembelajaran selama penelitian. Alat kedua berupa sejumlah pertanyaan yang dilontarkan kepada testee atau siswa pada waktu refleksi. Lembar pengamatan dan daftar pertanyaan untuk refleksi dapat dilihat pada lampiran. Data penelitian dikumpulkan melalui (1) pengamatan pembelajaran sebelum penelitian, yang terasa begitu berat dalam mengajarkan writing di kelas VII SMP Negeri 5 Kopang. (2) Pengisian angket oleh siswa sebelum dan sesudah penelitian dilakukan. (3) Pengisian lembar pengamatan 
proses pembelajaran selama penelitian oleh kolaborator dan peneliti sendiri. (4) Memberikan tes (pretes dan postes) materi penelitian pada siswa sebelum dan sesudah tindakan dilakukan.

Indikator keberhasilan penelitian ini adalah apabila ada peningkatan minat berdasarkan hasil angket sebelum dan sesudah penelitian yang dilakukan, maka tindakan dianggap berhasil dan apabila ada peningkatan hasil atau prestasi yang dulihat dari nilai berdasarkan hasil pretes dan postes penelitian. Atau menurut St Singgih (1998) apabila 85\% siswa berhasil mencapai nilai KKM (60), pada waktu postes materi penelitian, maka tindakan dianggap berhasil.

\section{HASIL DAN PEMBAHASAN}

\section{Siklus I}

Pada pertemuan pertama, proses pembelajaran dilakukan seperti biasanya. Diawali dengan pemberian motivasi, apersepsi dan penyampaian tujuan belajar hari itu. Kemudian sebelum tindakan dilaksanakan, kepada siswa dibagikan angket yang harus diisi dengan jujur. Agar supaya benar-benar jujur, identitas siswa tidak perlu dicantumkan. Dengan asumsi, kalau nama siswa dicantumkan, siswa akan kurang leluasa dalam mengisi angket, karena takut akan mempengaruhi nilai Bahasa Inggris mereka. Sedang kalau tanpa nama, siswa akan lebih leluasa dalam mengisi angket sesuai dengan kenyataan. Setelah pengisian angket selesai, lalu dikumpulkan. Ketika menyerahkan angket, kebanyakan siswa memilih diletakkan di bawah, supaya tidak kelihatan. Hasil angket sebelum tindakan dilaksanakan : dari 36 siswa, ada 3 siswa yang sangat berminat terhadap mata pelajaran Bahasa Inggris dengan skor 33, 34 dan 35. Yang berminat ada 20 siswa, dengan skor mulai dari 25 sampai dengan 32 . Yang kurang berminat ada 12 siswa dengan skor 21, 22, dan 23. Dan yang tidak berminat ada 1 siswa dengan skor 16. Setelah angket dikumpulkan, lalu dibagikan soal pretes dengan diberikan penjelasan seperlunya.

Hasil pretes adalah dari 36 siswa, satu siswa mendapat nilai 83, dua siswa mendapat 81 , dua siswa mendapat 80 , delapan siswa mendapat 76 , tiga siswa menmdapat 726 siswa mendpat 70 , dua siswa mendapat 68, enam siswa mendapat 64, empat siswa mendapat 61, dua siswa mendapat 56 dan dua siswa mendapat nilai 52. Berarti ada empat siswa yang belum mencapai nilai KKM. Kepada keempat siswa tersebut diminta memperbaiki atau membuat deskripsi yang lain di rumah, setelah deskripsi sebelumnya dibahas. Perbaikan dapat dikumpulkan pada pertemuan berikutnya.

Pada pertemuan kedua Setelah diberi motivasi, apersepsi dan disampaikan tujuan pelajaran hari itu, kemudian diperkenalkan metode mind mapping. Di sini dijelaskan tentang apa itu metode mind mapping, kegunaannya, aturan-aturannya serta cara pembuatannya. Semua siswa nampak tertarik dan memperhatikan ketika metode baru ini diperkenalkan. Mungkin karena sebelumnya belum pernah diperkenalkan suatu metode, atau karena ada kolaborator atau karena metodenya memang menarik bagi mereka. Yang penting, pada langkah pertama ini sudah kelihatan ada perubahan yang positif pada siswa. Lalu diikuti dengan implementasi metode tersebut dalam mempelajari descriptive text yang sudah pernah dipelajari dalam pembelajaran aspek reading. Di sini siswa juga nampak aktif menjawab pertanyaan-pertanyaan peneliti. Apalagi dalam mereview materi yang lalu itu, peneliti berusaha melibatkan sebanyak-banyaknya siswa, dengan memanggil nama-nama siswa dari segala penjuru kelas, walaupun mereka masih banyak yang diam dan yang menjawab hanya siswa-siswa yang pandai saja. Di akhir pembelajaran, siswa diberi tugas rumah (PR), mencari teks lain yang berbentuk deskriptif.

Sedangkan pada pertemuan ketiga setelah diberi motivasi, apersepsi dan disampaikan tujuan pembelajaran hari itu, siswa diminta mengeluarkan PRnya kemarin. Setelah diperiksa, ada yang sudah benar, ada yang keliru dengan report, ada yang belum menemukan dan ada yang belum mencari. Setelah itu siswa diajak meneliti pola kalimat yang terdapat dalam descriptive text. Yaitu pola kalimat Simple Present Tense. Lalu diterangkan pola-pola kalimat tersebut beserta contohnya Dalam memberikan contoh, peneliti selalu melibatkan siswa untuk menarik perhatiannya. Lalu siswa diminta berlatih membuat kalimat yang dikaitkan dengan tema " $H O B B Y$ " dan boleh dikerjakan bersama teman satu meja. Di akhir pelajaran diberi PR : menulis 5 macam hobi dalam Bahasa Inggris dan Indonesia.

Pada pertemuan keempat Setelah dilaksanakan kegiatan awal pembelajaran seperti biasa, peneliti mengumumkan 9 siswa yang meraih nilai pretes tertinggi. Kesembilan siswa diminta maju kedepan dan satu persatu diminta memilih satu persatu teman yang akan dijadikan anggota kelompoknya. Siswa yang dipilih langsung diminta maju kedepan, berdiri di belakang ketuanya. Kesempatan memilih dibuat sama, satu persatu, supaya adil. Setelah semua kelompok terbentuk, semua siswa diminta duduk satu meja bersama kelompoknya. Kepada masing-masing kelompok, lalu dibagikan LKS yang harus dikerjakan bersama kelompoknya. Tujuan diadakannya belajar kelompok adalah supaya siswa yang lemah bisa tertolong oleh siswa yang pandai. Dan juga dapat meringankan tugas guru (peneliti). LKS terlampir. Setelah selesai, LKS dikumpulkan untuk dinilai. 
Adapun pada pertemuan kelima dilaksanakan pembelajaran writing dengan metode mind mapping. Mula-mula peneliti memberikan contoh cara menulis dengan menggunakan metode mind mapping. Dengan bertanya tentang hobi kepada seorang siswa, peneliti menuliskan kata kuncinya pada mind mapping yang akan dibuat deskripsinya berdasarkan jawaban siswa tersebut.. Judul ditulis di tengah dan penjelasnya ditulis di sekelilingnya sesuai arah jarum jam. Setelah mind mapping jadi /cukup, lalu ditulis deskripsinya. Siswa mengikuti dengan baik. Lalu peneliti memberi waktu kepada siswa untuk menanyakan yang kurang jelas. Kemudian peneliti menawarkan latihannya akan dikerjakan sendiri-sendiri atau kelompok? Kebanyakan memilih kelompok, lalu siswa dipersilahkan berkumpul dengan kelompoknya masing-masing untuk menulis deskripsi yang diawali dengan pembuatan mind mapping seperti yang baru dicontohkan. Pekerjaan yang selesai dikumpulkan dan yang belum (2 kelompok) dilanjutkan di rumah.

Pada pertemuan keenam dibahas semua tugas kelompok yang dikerjakan pada pertemuan sebelumnya. Untuk mind mapping kebanyakan sudah benar, tapi untuk karangan, ada yang sudah baik, tapi kebanyakan masih perlu diperbaiki. Kebanyakan kesalahan terdapat pada grammar dan pemilihan kosa kata. Lalu diulas lagi grammarnya, dan pilihan kata yang benar. Setelah itu diberi tugas lagi, karena masih banyak yang salah. Tugas dikerjakan dalam kelompok lagi, dikumpulkan dan dinilai berdasarkan pedoman penilaian seperti pretes. Hasilnya : satu kelompok mendapat nilai 81 , dua kelompok mendapat nilai 76 , dua kelompok mendapat nilai 72 , satu kelompok mendapat nilai 68, satu kelompok mendapat nilai 64, satu kelompok mendapat nilai 62 dan satu kelompok mendapat nilai 52. Dari 9 kelompok, ada 1 kelompok yang belum mencapai nilai KKM (60). Untuk kelompok ini diminta memperbaiki di rumah dan diserahkan pada pertemuan berikutnya. Nilai perbaikan, maksimal 60, = nilai KKM.

Pada pertemuan ketujuh diadakan ulangan harian, yang juga berfungsi sebagai postes siklus pertama. Soal seperti pretes dengan tambahan mind mapping, karena sudah diperkenalkan mind mapping. Penilaiannya berdasarkan pedoman penilaian yang menyeluruh seperti dalam lampiran, mind mapping juga dinilai. Hasilnya adalah sebagai berikut : Untuk ulangan harian pada siklus 1 , hasilnya : satu siswa mendapat nilai 83 , dua siswa mendapat nilai 81 , dua siswa mendapat nilai 80 , delapan siswa mendapat nilai 76 , tiga siswa mendapat nilai 72 , enam siswa mendapat nilai 70 , dua siswa mendapat nilai 68, empat siswa mendapat nilai 64, empat siswa mendapat nilai 61 , dua siswa mendapat nilai 56 dan dua siswa mendapat nilai 52. Ada empat siswa yang belum mencapai nilai KKM (60). Kepada siswa yang belum tuntas belajar, diminta mengikuti program perbaikan, dengan mengulangi ulangan tersebut di rumah dan dikumpulkan pada pertemuan berikutnya.

Pada awal pertemuan kedelapan, setelah pemberian motivasi,apersepsi dan ulasan ulangan yang baru lalu, kemudian diadakan refleksi. Peneliti mengajukan berbagai pertanyaan seputar implementasi metode mind mapping secara lisan kepada seluruh siswa. Jawaban siswa dicatat, sebagai pertimbangan dalam merencanakan kegiatan siklus kedua. Daftar pertanyaan ada dalam lampiran.

\section{Siklus II}

Pada pertemuan pertama siklus ke 2, langsung diberikan pretes membuat procedure text. Siswa diminta menulis prosedur cara memasak atau membuat minuman dalam Bahasa Inggris. Metode yang baru dipelajari (metode mind mapping) juga diingatkan supaya digunakan untuk mempermudah penulisan. Langkah-langkah pembelajaran Three phase techniques juga tetap dilakukan.

Pada pertemuan kedua, diberikan 10 kosakata yang berkaitan dengan teks yang akan dipelajari, siswa diminta mencari artinya di kamus. Kemudian kata-kata tersebut dibuat kalimat imperative, dan dicoba untuk dipraktekkan. Kemudian mengerjakan soal latihan yang menyertainya secara berpasangan (mencari kata kerjanya). Juga soal-soal reading diberikan untuk mempermudah menulis.

Pada pertemuan ketiga, pembelajaran klasikal menjelaskan tentang apa itu procedure text beserta contoh dan retorikanya. Ciri-ciri umumnya, seperti jenis kalimat yang digunakan, kata sambung yang biasa digunakan, pola kalimat yang digunakan dlsb yang berkaitan dengan procedure text. Kemudian siswa diberi tugas kelompok untuk menulis prosedur cara membuat teh berdasarkan gambar yang diberikan dan didahului dengan membuat mind mappingnya. Setelah selesai dikumpulkan.

Pertemuan keempat membahas tugas kelompok yang baru lalu.Untuk materi ini relatif lebih mudah, sehingga kesalahan yang diperbuat siswapun relatif lebih sedikit. Selain itu, juga karena sudah mempunyai pengalaman pada siklus pertama. Kesalahan yang masih terjadi adalah kesalahan grammar dan kurang tepat dalam menggunakan kosakata. Setelah semua dibahas, tugas kelompok selanjutnya adalah membuat procedure lagi, dengan judul "How to make jelly". Selain dibuat mind mappingnya juga digambar prosesnya. Boleh diwarnai sebagus mungkin.

Pada pertemuan kelima diadakan evaluasi atau ulangan harian. Ulangan ini ulangan individu, kertas disediakan peneliti, siswa cukup membawa alat tulis dan pewarna saja. Tugasnya adalah menulis prosedur memasak atau membuat minuman seperti pada pretes. Hasilnya adalah : 2 siswa mendapat nilai 87, 2 siswa 
mendapat nilai 85,1 siswa mendapat nilai 83,8 siswa mendapat nilai 80, 3 siswa mendapat nilai 77, 5 siswa mendapat nilai 75, 2 siswa mendapat nilai 72, 2 siswa mendapat nilai 70, 4 siswa mendapat nilai 68, 1 siswa mendapat nilai 65 dan 3 siswa mendapat nilai 55 . Masih ada 3 siswa yang belum mencapai nilai KKM (60). Kepada 3 siswa yang belum tuntas belajar, diminta mengikuti program perbaikan, dengan mengulangi ulangan tersebut di rumah.

Pada pertemuan keenam, setelah evaluasi, kini tiba saatnya untuk refleksi. Refleksi kali ini dilakukan di luar kelas supaya lebih santai, suasana lebih rileks dan tidak membosankan. Anak laki-laki duduk di bangku taman di depan kelas dan anak perempuan duduk di bangku di depan kelas. Guru dan kolaborator berdiri diantara mereka. Guru mulai bertanya, siswa menjawab. Jawaban siswa dicatat. Setelah refleksi selesai, siswa diminta masuk ke dalam kelas. Kegiatan selanjutnya adalah pengisian angket kedua. Setelah selesai dikumpulkan. Sisa waktunya digunakan untuk ngobrol seputar penelitian..

Pada pertemuan ketujuh diadakan ulangan susulan dan pengisian angket susulan bagi yang belum ulangan dan mengisi angket.. Supaya tidak terganggu, ulangan dan pengisian angket dilakukan di perpustakaan sekolah. Setelah selesai dikumpulkan dan penelitian selesai. Selanjutnya pelajaran biasa di luar penelitian.

Berdasarkan analisis hasil ulangan pada siklus pertama, dari 36 siswa, ada 32 siswa yang dapat mencapai nilai KKM. Berarti ketuntasan belajar klasikalnya $=(32: 36) \times 100 \%=89 \%$. Kelas dikatakan tuntas belajarnya apabila minimum 85\% siswanya dapat mencapai nilai KKM. Berarti kelas ini tuntas belajarnya. Sedang pada siklus kedua, dari 36 siswa, ada 34 siswa yang dapat memperoleh nilai lebih besar sama dengan nilai KKM. Ada kenaikan ketuntasan belajar sebanyak $(2: 36) \times 100 \%=6 \%$. Daya serap siklus pertama $=70,69 \%$, dan daya serap siklus kedua $=76 \%$.

Setelah pembelajaran dengan metode mind mapping dilaksanakan, peneliti mengambil kesimpulan bahwa metode mind mapping dapat meningkatkan kompetensi dan prestasi writing siswa. Metode mind mapping sangat diperlukan dalam pembelajaran Bahasa Inggris khususnya pada kompetensi writing. Dengan membuat kerangka karangan dalam bentuk mind mapping yang dapat digambari dan diwarnai sesuka hati, dapat memotivasi siswa untuk mengekspresikan gagasannya melalui gambar yang beraneka ragam dan warna. Mind mapping juga dapat memunculkan ide, sehingga mempermudah siswa dalam menulis /mengarang. Selain itu, mind mapping juga dapat memunculkan kreatifitas, yang terlihat dari hasil karya siswa kelas
VII D SMP Negeri 5 Kopang yang bagus-bagus dan menarik, diluar dugaan peneliti.

Implementasi metode mind mapping dalam penulisan teks monolog berbentuk descriptive dan procedure benar-benar menarik minat siswa. Hal ini dibuktikan dengan catatan hasil pengamatan kolaborator Drs Muji Raharjo, guru Bahasa Inggris SMP Negeri 5 Kopang, yang memberi catatan bahwa siswa sangat senang atau antusias dalam mengikuti pelajaran dengan metode mind mapping. Siswa juga sangat aktif dalam mengikuti pelajaran. Penampilan guru dan materi yang disajikan cukup baik, mengena dan mudah diterima siswa. Pada waktu ulangan, semua siswa terlihat asyik dalam mengerjakan tugas dan semua siswa dapat menyelesaikan tugas itu dengan baik.

\section{SIMPULAN DAN SARAN}

\section{Simpulan}

Setelah pembelajaran dengan metode mind mapping dilaksanakan, peneliti mengambil kesimpulan sebagai berikut :

a. Metode mind mapping sangat diperlukan dalam pembelajaran Bahasa Inggris khususnya pada kompetensi writing. Dengan membuat kerangka karangan dalam bentuk mind mapping yang dapat digambari dan diwarnai sesuka hati, dapat memotivasi siswa untuk mengekspresikan gagasannya melalui gambar yang beraneka ragam dan warna. Mind mapping juga dapat memunculkan ide, sehingga mempermudah siswa dalam menulis /mengarang. Selain itu, mind mapping juga dapat memunculkan kreatifitas, yang terlihat dari hasil karya siswa kelas VII D SMP Negeri 5 Kopang yang bagus-bagus dan menarik, diluar dugaan peneliti.

b. Implementasi metode mind mapping dalam penulisan teks monolog berbentuk descriptive dan procedure benar-benar menarik minat siswa. Hal ini dibuktikan dengan catatan hasil pengamatan kolaborator Drs Muji Raharjo, guru Bahasa Inggris SMP Negeri 5 Kopang, yang memberi catatan bahwa siswa sangat senang atau antusias dalam mengikuti pelajaran dengan metode mind mapping. Siswa juga sangat aktif dalam mengikuti pelajaran. Penampilan guru dan materi yang disajikan cukup baik, mengena dan mudah diterima siswa. Pada waktu ulangan, semua siswa terlihat asyik dalam mengerjakan tugas dan semua siswa dapat menyelesaikan tugas itu dengan baik.

c. Berdasarkan analisis hasil ulangan pada siklus pertama, dari 36 siswa, ada 32 siswa yang dapat mencapai nilai KKM. Berarti ketuntasan belajar 
klasikalnya $=(32: 36) \times 100 \%=89 \%$. Kelas dikatakan tuntas belajarnya apabila minimum 85\% siswanya dapat mencapai nilai KKM. Berarti kelas ini tuntas belajarnya. Sedang pada siklus kedua, dari 36 siswa, ada 34 siswa yang dapat memperoleh nilai lebih besar sama dengan nilai KKM. Ada kenaikan ketuntasan belajar sebanyak $(2: 36) \times 100 \%=6 \%$. Daya serap siklus pertama $=70,69 \%$, dan daya serap siklus kedua $=76 \%$.

\section{Saran}

a. Guru Bahasa Inggris SMP supaya mencoba menggunakan metode mind mapping dalam pembelajaran kompetensi writing teks monolog. Selain menarik, karena dapat diberi gambargambar dan warna-warna sekehendak pembuatnya, juga dapat memunculkan kreatifitas siswa, memudahkan penulisan serta sesuai pendapat Buzan, dengan memanfaatkan gambar dan teks ketika kita mencatat atau mengeluarkan sesuatu yang ada di dalam diri, maka kita telah menggunakan dua belahan otak secara sinergis. Apalagi jika dalam peta pikiran itu, kemudian ditambahkan warna dan hal-hal yang memperkuat emosi ("Brain-Based Writing")

b. Para guru atau pendidik pada umumnya, juga dapat menggunakan metode ini dalam segala kompetensi pembelajaran, karena metode ini cukup menarik, dapat memunculkan ide dan kreatifitas, memuat berbagai metode, dan mengajak orang untuk berpikir global. Yang juga berarti mengaktifkan otak kanan. Orang yang berpikir dengan kedua belah otaknya (otak kanan dan otak kiri) akan memperoleh hasil yang maksimal dalam tugas atau pekerjaannya.

\section{UCAPAN TERIMA KASIH}

Dengan penuh rasa hormat, saya ucapkan teimakasih kepada:

1. Kepala Dinas Pendidikan Kabupaten Lombok Tengah yang telah memfasilitasi, mengizinkan penulis untk mengadakan penelitian hingga dapat terlaksana dengan baik.

2. Bapak Kepala sekolah yang selalu memberi dukungan sejak awal hingga terlaksananya penelitian ini dengan baik.

3. Guru-guru yang telah memberi dukungan baik secara moral maupun tindakan langsung dalam pelaksanaan penelitian ini.

\section{DAFTAR RUJUKAN}

Agustien, Helena IR. Kurikulum Bahasa Inggris SMP 2006. Kopang : Jogja English Teachers Association, 2006

BSNP. SK dan KD Bahasa Inggris - SMP, dilengkapi : SKL. Jakarta : BSNP, 2006

Depdiknas. Panduan Pengembangan Silabus Mata Pelajaran BAHASA INGGRIS SMP. Jakarta, 2006

Depdiknas Dirjen Manajemen Dikdasmen Direktorat Pembinaan Sekolah Menengah Pertama

Depdiknas. Panduan Pengembangan RPP Mata Pelajaran BAHASA INGGRIS SMP . Jakarta, 2006

Depdiknas Dirjen Menejemen Dikdasmen Direktorat Pembinaan SMP.

Depdiknas. Materi Pelatihan Terintegrasi BAHASA INGGRIS Buku 1. Jakarta, 2004

Depdiknas Dirjen Dikdasmen Direktorat Pendidikan Lamjutan Pertama.

Depdiknas. Buku Saku KTSP - SMP. Jakarta: Depdiknas Dirjen Menejemen, 2014

Indrotomo dkk. English On Sky 1 for Junior High School Students. Jakarta : Erlangga, 2004

Joko Siswanto dkk. Let's Talk Grade VII for Junior High School (SMP / MTs). Bandung : Pakar Raya, 2005

Kasihani, KE Suyanto dkk. English In Context 1- untuk SMP Kelas!. Jakarta : Bumi Aksara, 2005

Neuroscience Super Learning. Neuroscience Super Learning Progam BAHASA INGGRIS Tahap 1. Kopang : Pelatihan Peningkatan Mutu dan Profeionalisme guru Bahasa Inggris DIY, 2006

Syamsi Kastam. Penyusunan Proposal dan Laporan PTK. FBS UNY, 2014. 